\title{
Arthrobacter koreensis sp. nov., a novel alkalitolerant bacterium from soil
}

\author{
Jung-Sook Lee, ${ }^{1,2}$ Keun Chul Lee, ${ }^{1}$ Yu-Ryang Pyun ${ }^{2}$ and Kyung Sook Bae ${ }^{1}$ \\ ${ }^{1}$ Korean Collection for Type Cultures, Korea Research Institute of Bioscience and \\ Biotechnology, PO Box 115, Yusong, Daejeon 305-600, Korea \\ ${ }^{2}$ Department of Biotechnology, Yonsei University, Seoul 120-749, Korea
}

Two Arthrobacter strains, CA15-8 ${ }^{\top}$ and CA15-9, were isolated from soil, under alkali conditions, and characterized phenotypically, chemotaxonomically and genetically. These alkalitolerant organisms grew over a wide $\mathrm{pH}$ range $(\mathrm{pH} 7 \cdot 0-12 \cdot 0)$, with an optimum at $\mathrm{pH} 7 \cdot 0-8 \cdot 0$. The mean $\mathrm{G}+\mathrm{C}$ content of the DNA of these strains was $63 \pm 2$ mol\%. The strains contained MK- $8\left(\mathrm{H}_{2}\right)$ and MK-9 $\left(\mathrm{H}_{2}\right)$ as the main respiratory quinones. The cell-wall peptidoglycan was Lys-Thr-Ala and the whole-cell sugar was rhamnose. The major cellular fatty acids of the isolates were anteiso- $\mathrm{C}_{15: 0}$ and iso- $\mathrm{C}_{15 \text { :0 }}$. A phylogenetic analysis, based on $16 \mathrm{~S}$ rDNA sequence data, revealed that strains $\mathrm{CA} 15-8^{\top}$ and $\mathrm{CA} 15-9$ formed an evolutionary lineage distinct from other Arthrobacter species. On the basis of morphological, physiological and chemotaxonomic characteristics, 16S rDNA sequence comparisons and DNA-DNA hybridization data, a novel species of Arthrobacter is proposed, namely Arthrobacter koreensis (type strain CA15-8 ${ }^{\top}=\mathrm{KCTC}$ $9922^{\top}=$ IFO $16787^{\top}$ ).

The genus Arthrobacter was first proposed by Conn \& Dimmick (1947) and its description was emended by Koch et al. (1995). At the time of writing, there are 35 recognized species of the genus Arthrobacter (http://www.bacterio. cict.fr/a/arthrobacter.html), which are reported as being phenotypically heterogeneous. Members of the genus Arthrobacter are Gram-positive, aerobic, catalase-positive, coryneform bacteria. They have L-lysine as the diamino acid in their cell walls and have branched cellular fatty acids (Funke et al., 1997). They have been divided into two groups on the basis of their peptidoglycan (Schleifer \& Kandler, 1972). Group I, designated A3 $\alpha$, contains peptidoglycan variations where the murein cross-linkage is by interpeptide bridges involving monocarboxylic L-amino acids or glycine or both. Arthrobacter globiformis, the type species of the genus, and most other Arthrobacter species are included in group I. By contrast, several other Arthrobacter species with A4 peptidoglycan are included in group II. The A $4 \alpha$ variation involves cross-linkage of peptidoglycan by interpeptide bridges containing a dicarboxylic acid such as L-Lys-Ala-Glu or L-Lys-Glu.

Published online ahead of print on 7 March 2003 as DOI 10.1099/ ijs.0.02492-0.

The GenBank accession numbers for the 16S rDNA sequences of Arthrobacter koreensis strains CA15-8 ${ }^{\top}$ and CA15-9 are AY116496 and AY116497, respectively.

A more-detailed phylogenetic tree showing the position of strains CA15-8 ${ }^{\top}$ and CA15-9 within the genus Arthrobacter is available in IJSEM Online.
The genus Arthrobacter constitutes a predominant group of micro-organisms found in soils from various environments all over the world. Many mesophilic and psychrophilic arthrobacters have been reported. However, alkaliphilic or alkalitolerant arthrobacters have rarely been reported. During taxonomic studies, and isolation under alkali conditions, we characterized Arthrobacter-like isolates from soil. In this study, we describe the morphological, biochemical and phylogenetic characteristics of alkalitolerant bacteria isolated from soil. On the basis of these data, we propose the description of a novel species of Arthrobacter, Arthrobacter koreensis.

Strains CA15-8 ${ }^{\mathrm{T}}$ and CA15-9 were isolated from soil from Daejeon City, Korea. They were isolated on trypticase/soy agar (TSA) at $\mathrm{pH} 10 \cdot 0$ and cultured on TSA (neutral $\mathrm{pH}$ ) for $48 \mathrm{~h}$ at $30^{\circ} \mathrm{C}$, for use in morphological, biochemical and molecular studies.

The morphology and motility of cells were examined by light microscopy using the hanging-drop technique (Skerman, 1967). API tests (bioMérieux) 20NE, API 20E and API Coryne, performed in accordance with the manufacturer's directions, were used for physiological and biochemical characterizations. Catalase activity was determined by the production of bubbles from $3 \%(\mathrm{v} / \mathrm{v}) \mathrm{H}_{2} \mathrm{O}_{2}$, and oxidase activity was determined using $1 \%(\mathrm{w} / \mathrm{v})$ $N, N, N^{\prime}, N^{\prime}$-tetramethyl-p-phenylenediamine. A GP Biolog microplate, containing 95 different carbon compounds, was used to test for substrate oxidation. 
Cells of the isolates were Gram-positive, had a rod-coccus life cycle and were motile. Strains CA15-8 ${ }^{\mathrm{T}}$ and CA15-9 formed round, smooth, yellow colonies on TSA. Both strains tested positive for nitrate reduction, catalase, indole production, acetoin production, pyrazinamidase, alkaline phosphatase and $\alpha$-glucosidase, and for the assimilation of glucose, mannose, mannitol, maltose, gluconate and malate. In the Biolog microplates, the organisms oxidized Tween 40, Tween 80, D-arabitol, D-ribose, xylitol, acetic acid, p-hydroxyphenylacetic acid, methyl pyruvate, pyruvic acid, adenosine, $2^{\prime}$-deoxyadenosine, inosine, thymidine, uridine and thymidine 5'-monophosphate. Arthrobacter luteolus KCTC $9907^{\mathrm{T}}$, which is closely related to strains CA15-8 ${ }^{\mathrm{T}}$ and CA15-9, showed some differences in the Biolog test. It oxidized L-rhamnose and glycerol but not D-arabitol or p-hydroxyphenylacetic acid.

Growth experiments were performed using screw-cap tubes $(20 \times 150 \mathrm{~mm})$ containing $10 \mathrm{ml}$ trypticase soy broth (TSB) adjusted to $\mathrm{pH}$ values ranging from $6 \cdot 0$ to $13 \cdot 0$. Growth was estimated by monitoring the $\mathrm{OD}_{650}$ value. TSB media containing $100 \mathrm{mM} \mathrm{Na} \mathrm{HPO}_{4} / \mathrm{NaH}_{2} \mathrm{PO}_{4}$ buffer at $\mathrm{pH} 6 \cdot 0-8 \cdot 0,100 \mathrm{mM} \mathrm{NaHCO} / \mathrm{Na}_{2} \mathrm{CO}_{3}$ buffer at pH 9.0-10 0, $50 \mathrm{mM} \mathrm{Na}{ }_{2} \mathrm{HPO}_{4} / 100 \mathrm{mM} \mathrm{NaOH}$ buffer at pH $11 \cdot 0$ or $100 \mathrm{mM} \mathrm{KCl} / \mathrm{NaOH}$ buffer at $\mathrm{pH} 12 \cdot 0-13 \cdot 0$ were used. These experiments were performed on the basis of the methods of Yumoto et al. (1998). Strains CA15-8

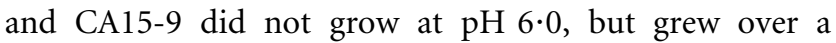
wide $\mathrm{pH}$ range $(\mathrm{pH} 7 \cdot 0-12 \cdot 0)$. Growth was more rapid at $\mathrm{pH} 7 \cdot 0-8 \cdot 0$ than at the other $\mathrm{pH}$ values tested. This was an important characteristic for distinguishing these isolates from most of the other Arthrobacter species, and indicated they were alkalitolerant organisms (Yumoto et al., 1998).

For analysis of their total cellular fatty acid content, cells of strains CA15- $8^{\mathrm{T}}$ and CA15-9 were cultured on TSA for
$48 \mathrm{~h}$ at $30^{\circ} \mathrm{C}$. The fatty acids were extracted by following the Microbial Identification System protocol, as described previously (Lee et al., 1996; Yang et al., 1993). Isoprenoid quinones were extracted with chloroform/methanol $(2: 1$, $\mathrm{v} / \mathrm{v})$, then purified by TLC on Merck Kieselgel $60 \mathrm{~F}_{254}$ plates $(20 \times 20 \mathrm{~cm}, 0.5 \mathrm{~mm}$ thickness $)$ using petroleum ether/diethyl ether $(9: 1, \mathrm{v} / \mathrm{v})$ as the eluting solvent. The identity of the quinone was determined by HPLC analysis, as described by Shin et al. (1996). Peptidoglycan and whole-cell sugars were determined by the method of Komagata \& Suzuki (1987). The peptidoglycan was hydrolysed, and the amino acids were subjected to HPLC (using Waters equipment).

Strains CA15-8 ${ }^{\mathrm{T}}$ and CA15-9 had anteiso- $\mathrm{C}_{15: 0}$ and iso$\mathrm{C}_{15: 0}$ as their major fatty acids, $\mathrm{MK}-8\left(\mathrm{H}_{2}\right)$ and $\mathrm{MK}-9\left(\mathrm{H}_{2}\right)$ as their main respiratory quinones, rhamnose as their whole-cell sugar and Lys-Thr-Ala ${ }_{2}$ as their cell-wall peptidoglycan. Of the Arthrobacter species, Arthrobacter citreus and $A$. luteolus are the only two species known to have Lys-Thr-Ala 2 peptidoglycans. A comparison between the phenotypic and chemotaxonomic characteristics of our isolates and those of $A$. citreus and A. luteolus is shown in Table 1. As shown in Fig. 1, strains CA15- $8^{\mathrm{T}}$ and CA15-9 were phylogenetically closely related to $A$. citreus and A. luteolus [a more-detailed phylogenetic tree is available in IJSEM Online (http://ijs.sgmjournals.org)]. Under identical growth conditions (TSA media at $30{ }^{\circ} \mathrm{C}$ and $\mathrm{pH} 7 \cdot 3$ ), A. luteolus KCTC $9907^{\mathrm{T}}$ had the same cellular fatty acids and menaquinone profile as our novel strains, but the relative contents were different. A. luteolus KCTC $9907^{\mathrm{T}}$ had anteiso- $\mathrm{C}_{15: 0}(72 \cdot 6 \%)$ and iso- $\mathrm{C}_{15: 0}(14 \cdot 1 \%)$, but strains CA15-8 $8^{\mathrm{T}}$ and CA15-9 had anteiso- $\mathrm{C}_{15: 0}(40 \cdot 0 \%)$ and iso- $\mathrm{C}_{15: 0}(34 \cdot 4 \%)$. With regard to its menaquinones, A. luteolus KCTC $9907^{\mathrm{T}}$ was found to have $68 \% \mathrm{MK}-9\left(\mathrm{H}_{2}\right)$ and $22 \% \mathrm{MK}-8\left(\mathrm{H}_{2}\right)$. In contrast, strains $\mathrm{CA} 15-8^{\mathrm{T}}$ and

Table 1. Some characteristics of Arthrobacter species with Lys-Thr-Ala ${ }_{2}$ type peptidoglycan

Data for A. citreus SAM $0302^{\mathrm{T}}$ are from Kodama et al. (1992). All strains are motile, reduce nitrate and produce $\alpha$-glucosidase. None of the strains have activities for pyrrolidonyl peptidase, $\mathrm{N}$-acetylglucosaminidase or urease. All of the strains utilize D-glucose and D-ribose. ND, Not determined; w, weak reaction.

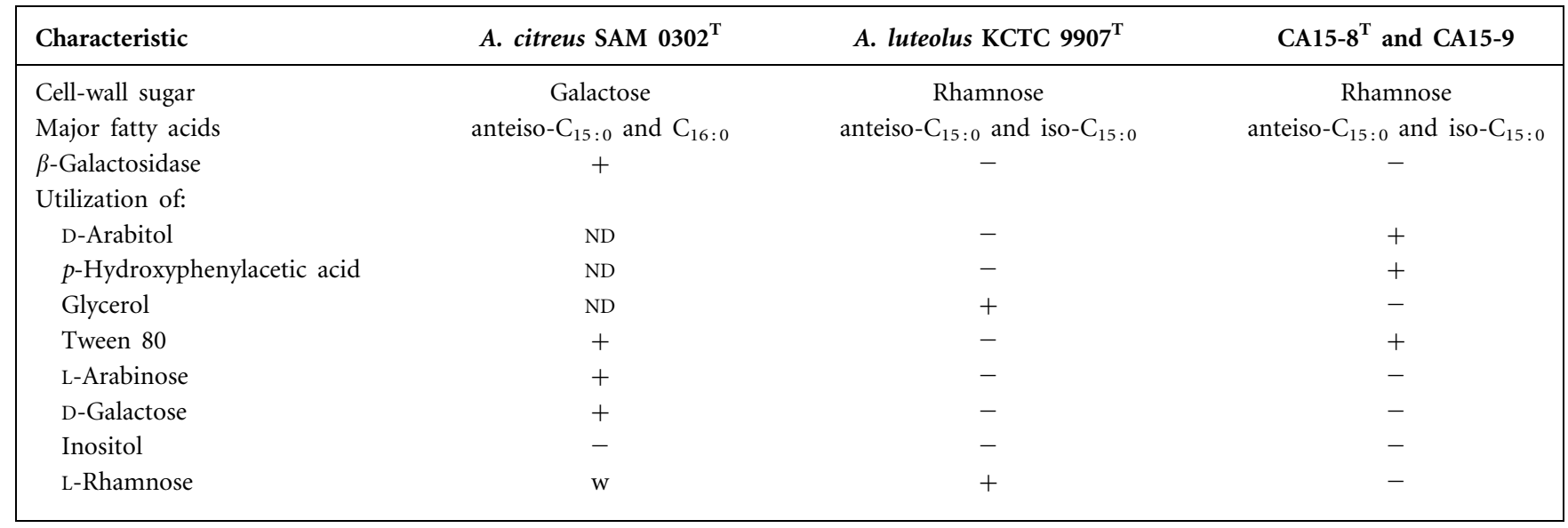




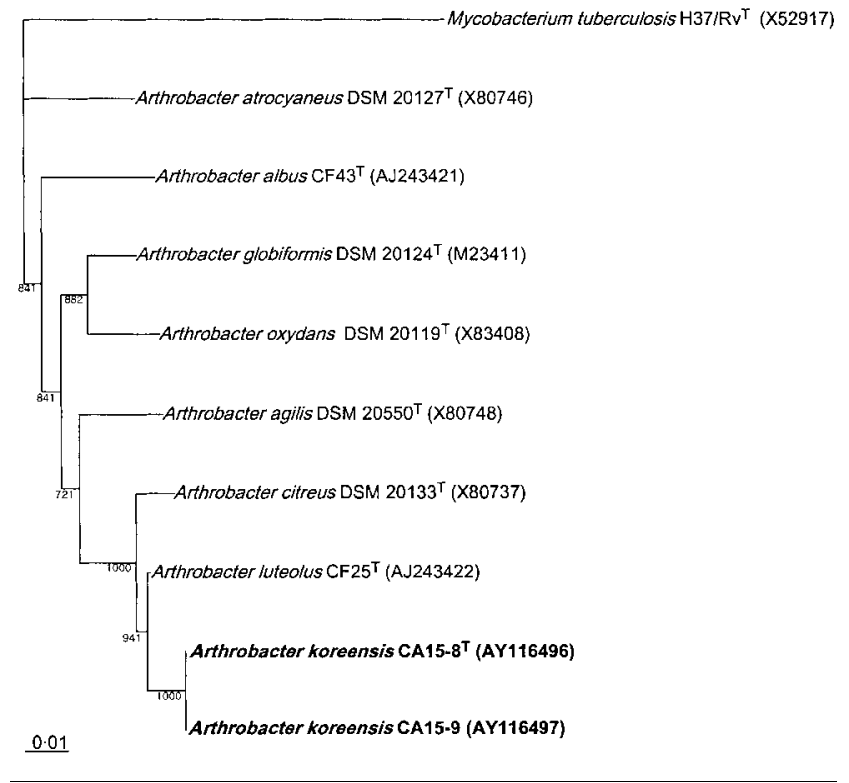

Fig. 1. Phylogenetic tree, based on 16S rRNA gene sequences, showing the position of strains $C A 15-8^{\top}$ and CA15-9 with respect to other species of the genus Arthrobacter. The branching pattern was generated by the neighbourjoining method. Accession numbers are given in parentheses. The numbers at the nodes indicate bootstrap values (1000 replications). Bar, 0.01 accumulated changes per nucleotide.

CA15-9 had $43 \pm 2 \%$ MK- $8\left(\mathrm{H}_{2}\right)$ and $35 \pm 1 \%$ MK-9 $\left(\mathrm{H}_{2}\right)$. The other percentage $(22 \pm 3 \%)$ showed the sum of minor peaks in the analysis of quinone by HPLC. The minor peaks appeared in less than $4 \%$ and were not studied in detail. It has been reported that the Arthrobacter species contain MK-9 $\left(\mathrm{H}_{2}\right)$ or MK-8 and MK-9 as the predominant menaquinone(s). However, strains CA15- ${ }^{\mathrm{T}}$ and CA15-9 contain $\mathrm{MK}-8\left(\mathrm{H}_{2}\right)$ as the predominant menaquinone together with significant amounts of MK-9 $\left(\mathrm{H}_{2}\right)$. This characteristic distinguishes these strains from other species of Arthrobacter.

DNA was extracted and then purified by a modification of the method of Marmur (1961). The G+C content of the DNA was determined by the reversed-phase HPLC method described by Tamaoka \& Komagata (1984). The DNA G + C content of strains CA15- $8^{\mathrm{T}}$ and CA15-9 was $63 \pm 2 \mathrm{~mol} \%$, while that of A. luteolus KCTC $9907^{\mathrm{T}}$ was $63 \mathrm{~mol} \%$.

Two universal primers (9F and 1542R) described by Stackebrandt \& Liesack (1993) were used for PCR amplification of the 16S rRNA gene. The amplified PCR product was purified using a QIAquick PCR purification kit (Qiagen). The purified 16S rDNA was sequenced using the ABI Prism BigDye Terminator cycle sequencing ready reaction kit (Applied Biosystems), with an automated DNA sequencer (model 377; Applied Biosystems). Nearly complete $16 \mathrm{~S}$ rDNA sequences (1459 bp) of strains CA15- $8^{\mathrm{T}}$ and CA15-9 were determined. The $16 \mathrm{~S}$ rDNA sequences of these strains were aligned with the 16S rRNA and rDNA sequences of representatives of the genus Arthrobacter and related taxa, using CLUSTAL $\mathrm{W}$ software (Thompson et al., 1994). A phylogenetic tree was constructed using the neighbour-joining method (Saitou \& Nei, 1987) based on distance-matrix data. The evolutionary distances were calculated using the Jukes-Cantor model (Jukes \& Cantor, 1969). The PHYLIP software package (Felsenstein, 1993) was used for all analyses. The topology of the phylogenetic tree was evaluated with bootstrap analysis (Felsenstein, 1985) of the neighbour-joining data, based on 1000 replications.

The primary structures of the $16 \mathrm{~S}$ rDNA sequences of strains CA15- $8^{\mathrm{T}}$ and CA15-9 were compared with those of closely related reference strains. A phylogenetic tree, based on the $K_{\text {nuc }}$ value (Fig. 1), indicates that these strains belong to the genus Arthrobacter.

Strains CA15-8 ${ }^{\mathrm{T}}$ and CA15-9 had identical $16 \mathrm{~S}$ rRNA gene sequences and morphological, physiological and chemotaxonomic characteristics, implying that they may be members of the same species. Our novel strains were phylogenetically most closely related to A. luteolus KCTC $9907^{\mathrm{T}}$ (98.9\% sequence similarity), but formed a distinct cluster with this strain (Fig. 1). The levels of sequence similarity between strains CA15- $8^{\mathrm{T}}$ and CA15-9 and other Arthrobacter species ranged from $87 \cdot 4$ to $98 \cdot 9 \%$.

DNA-DNA hybridization was done by the membrane filter technique using DIG High Prime DNA Labelling and Detection Starter Kit II (Roche Molecular Biochemicals). Genomic DNA (200 ng) was denatured by the alkaline method, then immobilized on a nylon membrane (Hybond- ${ }^{+}$; Amersham) by applying a small vacuum. DNA preparations were labelled with DIG High Prime DNA Labelling and Detection Starter Kit II. The denatured DNA samples $(1 \mu \mathrm{g})$ were labelled according to the manufacturer's protocol. The membranes were prehybridized in a hybridization solution at $52^{\circ} \mathrm{C}$ for $30 \mathrm{~min}$. The actual hybridization was carried out in a hybridization solution containing labelled DNA $\left(25 \mathrm{ng} \mathrm{ml}^{-1}\right)$ at $52{ }^{\circ} \mathrm{C}$ for $16 \mathrm{~h}$. After hybridization, the membranes were washed twice in primary washing solution $(2 \times$ SSC, $0.1 \%$ SDS $)$ and subsequently washed twice in a secondary solution $(0.5 \times$ SSC, $0.1 \%$ SDS $)$ at $68^{\circ} \mathrm{C}$. Detection reagents were added to the membranes for $5 \mathrm{~min}$ at room temperature, then the excess liquid was squeezed out. The membranes were exposed to autoradiography film (Hyperfilm-ECL; Amersham) for $10 \mathrm{~min}$, and the signal intensities were determined using the TINA 2.0 program. The signal produced by self-hybridization was taken as $100 \%$, and percentage homology values were calculated from duplicate samples.

DNA-DNA hybridization values between the two novel isolates, CA15-8 $8^{\mathrm{T}}$ and CA15-9, and the reference strain A. luteolus KCTC $9907^{\mathrm{T}}$ were below $8 \%$. DNA-DNA hybridization values between strains CA15- $8^{\mathrm{T}}$ and CA15-9 showed high levels of homology (90-104\%) between the two strains. 
The phylogenetic definition of a species generally involves 'strains with approximately $70 \%$ or greater DNA-DNA relatedness' (Wayne et al., 1987). According to the available compiled data, organisms that have less than $97.0 \%$ sequence homology will not reassociate to more than $60 \%$, no matter which hybridization method is applied (Stackebrandt \& Goebel, 1994). The results of the phylogenetic and DNA-DNA hybridization analyses demonstrated that strains CA15-8 ${ }^{\mathrm{T}}$ and CA15-9 were not related to any of the recognized members of the genus Arthrobacter at the species level.

On the basis of morphological, physiological and chemotaxonomic characteristics, DNA-DNA hybridization data and $16 \mathrm{~S}$ rDNA sequence comparisons, we propose a novel species of the genus Arthrobacter, namely Arthrobacter koreensis, to accommodate strains CA15- $8^{\mathrm{T}}$ and CA15-9 ( = KCTC 9923=IFO 16788), two organisms isolated from soil from Daejeon City, Korea.

\section{Description of Arthrobacter koreensis sp. nov.}

Arthrobacter koreensis (ko.re.en'sis. N.L. adj. koreensis pertaining to Korea, where the organisms were isolated).

Gram-positive and coryneform. Cells are motile. Colonies on trypticase/soy agar are round, smooth and yellow. Tests for the reduction of nitrate, the production of catalase, indole, acetoin, pyrazinamidase, alkaline phosphatase and $\alpha$-glucosidase, and the assimilation of glucose, mannose, mannitol, maltose, gluconate and malate are all positive. Oxidizes Tween 40, Tween 80, D-arabitol, D-ribose, xylitol, acetic acid, $p$-hydroxyphenylacetic acid, methyl pyruvate, pyruvic acid, adenosine, 2'-deoxyadenosine, inosine, thymidine, uridine and thymidine $5^{\prime}$-monophosphate. Cells are alkalitolerant and do not grow at $\mathrm{pH} 6 \cdot 0$, but they do grow at $\mathrm{pH} 7 \cdot 0-12 \cdot 0$, with an optimum at $\mathrm{pH} 7 \cdot 0-8 \cdot 0 . \mathrm{G}+\mathrm{C}$ content of the DNA is $63 \pm 2 \mathrm{~mol} \%$. Major isoprenoid quinones are menaquinones $\mathrm{MK}-8\left(\mathrm{H}_{2}\right)$ and MK-9 $\left(\mathrm{H}_{2}\right)$. Major cellular fatty acids are anteiso- $\mathrm{C}_{15: 0}$ and iso- $\mathrm{C}_{15: 0}$. Cell-wall peptidoglycan contains Lys-Thr$\mathrm{Ala}_{2}$, and the whole-cell sugar is rhamnose. Isolated from soil from Daejeon City in Korea.

The type strain is CA15-8 ${ }^{\mathrm{T}}\left(=\right.$ KCTC $\left.9922^{\mathrm{T}}=\mathrm{IFO} 16787^{\mathrm{T}}\right)$.

\section{Acknowledgements}

We thank Professor Hans G. Trüper for his advice on the naming of the species. This study was supported financially by grant KBM1000212 from the Korea Research Council of Fundamental Science and Technology.

\section{References}

Conn, J. \& Dimmick, I. (1947). Soil bacteria similar in morphology to Mycobacterium and Corynebacterium. J Bacteriol 54, 291-303.

Felsenstein, J. (1985). Confidence limits on phylogenies: an approach using the bootstrap. Evolution 39, 783-791.
Felsenstein, J. (1993). PHYLIP (phylogeny inference package), version 3.5c. Department of Genetics, University of Washington, Seattle, USA.

Funke, G., von Graevenitz, A., Clarridge, J. E., III \& Bernard, K. A. (1997). Clinical microbiology of coryneform bacteria. Clin Microbiol Rev 10, 125-159.

Jukes, T. H. \& Cantor, C. R. (1969). Evolution of protein molecules. In Mammalian Protein Metabolism, pp. 21-132. Edited by H. N. Munro. New York: Academic Press.

Koch, C., Schumann, P. \& Stackebrandt, E. (1995). Reclassification of Micrococcus agilis (Ali-Cohen 1889) to the genus Arthrobacter as Arthrobacter agilis comb. nov. and emendation of the genus Arthrobacter. Int J Syst Bacteriol 45, 837-839.

Kodama, Y., Yamamoto, H., Amano, N. \& Amachi, T. (1992). Reclassification of two strains of Arthrobacter oxydans and proposal of Arthrobacter nicotinovorans sp. nov. Int J Syst Bacteriol 42, 234-239.

Komagata, K. \& Suzuki, K.-I. (1987). Lipid and cell-wall analysis in bacterial systematics. In Methods in Microbiology, vol. 19, pp. 161-207. Edited by R. R. Colwell \& R. Grigorova. New York: Academic Press.

Lee, J.-S., Jung, M.-C., Kim, W.-S. \& 10 other authors (1996). Identification of lactic acid bacteria from kimchi by cellular FAMEs analysis. Kor J Appl Microbiol Biotechnol 24, 234-241.

Marmur, J. (1961). A procedure for the isolation of DNA from microorganisms. J Mol Biol 3, 208-218.

Saitou, N. \& Nei, M. (1987). The neighbor-joining method: a new method for reconstructing phylogenetic trees. Mol Biol Evol 4, 406-425.

Schleifer, K. H. \& Kandler, O. (1972). Peptidoglycan types of bacterial cell walls and their taxonomic implications. Bacteriol Rev 36, 407-477.

Shin, Y. K., Lee, J.-S., Chun, C. O., Kim, H.-J. \& Park, Y.-H. (1996). Isoprenoid quinone profiles of the Leclercia adecarboxylata KCTC $1036^{\mathrm{T}}$. J Microbiol Biotechnol 6, 68-69.

Skerman, V. B. D. (1967). A Guide to the Identification of the Genera of Bacteria, 2nd edn. Baltimore: Williams \& Wilkins.

Stackebrandt, E. \& Goebel, B. M. (1994). Taxonomic note: a place for DNA-DNA reassociation and 16S rRNA sequence analysis in the present species definition in bacteriology. Int J Syst Bacteriol 44, 846-849.

Stackebrandt, E. \& Liesack, W. (1993). Nucleic acids and classification. In Handbook of New Bacterial Systematics, pp. 152-189. Edited by M. Goodfellow \& A. G. O’Donnell. London: Academic Press.

Tamaoka, J. \& Komagata, K. (1984). Determination of DNA base composition by reversed phase high-performance liquid chromatography. FEMS Microbiol Lett 25, 125-128.

Thompson, J. D., Higgins, D. G. \& Gibson, T. J. (1994). CLUSTAL W: improving the sensitivity of progressive multiple sequence alignment through sequence weighting, position-specific gap penalties and weight matrix choice. Nucleic Acids Res 22, 4673-4680.

Wayne, L. G., Brenner, D. J., Colwell, R. R. \& 9 other authors (1987). International Committee on Systematic Bacteriology. Report of the ad hoc committee on reconciliation of approaches to bacterial systematics. Int J Syst Bacteriol 37, 463-464.

Yang, P., Vauterin, L., Vancanneyt, M., Swings, J. \& Kersters, K. (1993). Application of fatty acid methyl esters for the taxonomic analysis of the genus Xanthomonas. Syst Appl Microbiol 16, 47-71.

Yumoto, I., Yamazaki, K., Sawabe, T., Nakano, K., Kawasaki, K., Ezura, Y. \& Shinano, H. (1998). Bacillus horti sp. nov., a new gramnegative alkaliphilic bacillus. Int J Syst Bacteriol 48, 565-571. 